\title{
A NEW TRIAL FOR BIOFORMATION OF ANTIMICROBIAL AGENT CONTROLLING MULTI DRUG RESISTANT MICROORGANISM
}

\author{
${ }^{1}$ Ahmed Sadoun Mohamed, ${ }^{1}$ Ayman A. Farrag , ${ }^{2} *$ Mahmoud Mohamed Elaasser, \\ ${ }^{1}$ Mohamed Ali Elbadry \\ ${ }^{1}$ Department of Botany and Microbiology, Faculty of Science, Al-Azhar University, \\ Cairo, Egypt \\ ${ }^{2}$ Assistant professor of Microbiology - The Regional Center for Mycology and biotechnology, \\ Al-Azhar University, Cairo
}

\begin{abstract}
:
In the present investigation, a trial was done to find a new antimicrobial agent producing microbe from soil microbiota of local habitats to control the problem of multiple drug resistance. The term of Antimicrobial resistance (AMR) is used to describe microorganisms that can resist the effects of drugs and chemicals designed to kill them. Seventy six actinomycetes isolates were isolated from fifteen soil samples different localities in Egypt were primary screening for antimicrobial activity by agar plug diffusion method against test microorganisms. Sixteen isolates were selected for secondary screening in small scale submerged fermentation system and assayed against pathogenic tested microorganisms using agar well diffusion method. Among of these isolates tested, the isolate (S1SHA1) showed the highest antimicrobial activity against pathogenic test organisms. This isolate was identified as Streptomyces griseoplanus by morphological, physiological, biochemical characters and 16s rRNA gene sequence. Physical and nutritional factors affecting activity of antimicrobial agent were studied. The results showed that, optimum activity of antimicrobial agent achieved with $\mathrm{pH} 7$, incubation temperature $28 \mathrm{C}$, for 7 days, at $150 \mathrm{rpm}$ agitation, carbon and nitrogen source starch $1.5 \%$ and potassium nitrate $0.4 \%$, as well as phosphorus $2 \mathrm{~g} / \mathrm{l}$ and $\mathrm{NaCl}$ at concentration of $1 \%$. Antimicrobial agent from batch culture was subjected to extraction and purification processes using ethyle acetate and preparative TLC, respectively. Determination of minimum inhibitory concentrations (MIC) and Mode of action of antimicrobial agent produced by $S$. griseoplanus (S1SHA1) on the test microbial strains using Transmission Electron Microscopy (TEM). Cytotoxic studies showed that no cytotoxic effects were observed for the compound when tested even at high concentrations
\end{abstract}

*Corresponding Author: mmelaaser@azhar.edu.eg

\section{Keywords:}

Pathogenic microorganism, Antimicrobial agent, Multidrug resistant, Cytotoxicity 


\section{INTRODUCTION:-}

Scientists all over the world are endeavoring continuously to search for new antibiotic compounds in order to tackle the serious consequences and dynamic nature of antibiotic resistance. The term of Antimicrobial resistance (AMR) is used to describe microorganisms that can resist the effects of drugs and chemicals designed to kill them (Thornber et al., 2020 ; Vela Gurovic and Olivera, 2017).

Actinomycetes comprise an extensive and diverse group of Gram-positive aerobic mycelial bacteria. They are widely distributed group in nature, particularly the soil inhabit (AitBarka et al., 2016). They have produced many important bioactive substances with high pharmaceutical values and approximately two-thirds of antibiotics (Saadoun et al., 2015). Almost $80 \%$ of the world's antibiotics are known to produce from actinomycetes, mostly from the genera Streptomyces and Micromonospora (Saadoun et al., 2015).

Actinobacteria are known as biofactories of enzymes, with applications in the textile, bio-refineries, food, pulp and paper, agriculture, detergent and pharmaceutical industries (Richa and Vivek, 2018).

The majority of the actinomycetes inhabit in soil that are essential drug sources remain uncultivable, as a result, inaccessible for novel antibiotic discovery. Goodfellow and Haynes, 1984 reviewed the literature on isolation of actinomycetes and suggested that only $10 \%$ of the actinomycetes are isolated from nature. Most of the antibiotics in use today are derivatives of secondary metabolites produced by actinomycetes and fungi (Butler and Buss, 2006; Newman and Cragg, 2007). Actinomycetes can be isolated from soil and marine sediments. Although the pharmaceutical industry has screened soils for about 50 years, only a small fraction of the surface of the globe has sampled, and only a small fraction of actinomycetes taxa has been discovered (Al-Ghazali and Omran, 2017).

Filamentous soil bacteria belonging to the genus Streptomyces widely recognized as industrially relevant microorganisms because of their ability to produce many kinds of novel secondary metabolites including antibiotics and enzymes (Williams et al., 1983). Indeed, different Streptomyces species produces about $75 \%$ of commercially and medically useful antibiotics (Miyadoh, 1993).

Under different conditions, antibiotics production by Streptomyces, it is possible to improve or lose altogether, so promoting the growth and production of secondary metabolites from Streptomyces can be carried out by manipulating the nutritional, chemical, and physical parameters of the culturing conditions. The cultural factor optimization plays a remarkable role in the productivity and economics of the essential process (Al-Ghazali and Omran, 2017). Hence, we need to screen more and more actinomycetes from different habitats for antimicrobial sources in the hope of getting some actinomycetes strains producing new antibiotics that have not been discovered yet and active against multiple drug-resistant pathogens. Therefore, our study was aimed to the isolation of Streptomyces sp. having the ability to produce antibacterial metabolites and optimize some 
environmental parameters for excellent antimicrobial metabolite production.

\section{Materials and Methods:-}

\section{Samples:}

A total of 15 soil samples were collected from the rhizosphere of plants and agricultural soils from field sites of locations in Al-Sharqia Governorate - Anshas El Raml 11 samples (Lat,30²2'33.2"N; Long. 31 ${ }^{\circ} 26^{\prime} 40.3^{\prime \prime E}$ ) and locations in Qaliobia Governorate - Abu Zaabal 4 samples (Lat, 30¹7'06.6"N; Long. 31²3'00.4" E) The samples were placed in sterile plastic containers separately, tightly sealed and transported to the laboratory. Samples were air dried for one week. After a week, heat treatment was performed by holding the sediment samples in a water bath at $50^{\circ} \mathrm{C}$ for $60 \mathrm{~min}$ for prevention of other bacterial flora (Takizawa et al., 1993).

\section{Media used for isolation:-}

For isolation of Actinomycetes, the following two media were used, Starch Casein Agar medium (SCA) $\mathrm{pH}$ was adjusted to 7.0 before sterilization (Arifuzzaman et al., 2010) and Actinomycetes Isolation Agar (AIA) were used and pH was adjusted to 7 before- sterilization (Awad et al., 2009).

\section{Isolation and Maintenance of Actinomycetes Isolates:-}

Actinomycetes were isolated by serial dilution plate technique (Arifuzzaman et al., 2010). About $1 \mathrm{~g}$ of each soil sample was suspended in $10 \mathrm{ml}$ of sterile normal saline $(0.85 \%)$ and shaken on orbital shaker for about $30 \mathrm{~min}$ at $121 \mathrm{rpm}$; the suspension was left for $30 \mathrm{~min}$ in the Laminar Air Flow hood. Consequently, $1 \mathrm{ml}$ of sample was taken and diluted 4 fold in $9 \mathrm{ml}$ of sterile normal saline $(0.85 \%)$. The suspensions were agitated with vortex and $0.1 \mathrm{ml}$ of sample was taken from 10-1, 102, 10- 3, and 10 - 4 dilutions that was then spread on each of the Starch Casein Agar medium and Actinomycetes Isolation Agar medium. The plates were incubated, at 30 ${ }^{\circ} \mathrm{C}$ for six to ten days (Dhanasekaran et al., 2009). All isolates were identified as actinomycetes based on colony morphology and color of mycelium (Williams and Cross, 1971). This work was done at the AL-Azhar center for Fermentation Biotechnology \& Applied Microbiology, AL-Azhar University, Cairo, Egypt.

\section{Primary screening of the isolated microorganisms for Antimicrobial activity:-}

A total of 76 isolates were primarily screened for antimicrobial activity against four test microorganisms Bacillus subtilis NRRL B 543, Staphylococcus aureus ATCC 29213, Escherichia coli ATCC 25922 and Candida albicans MTCC183 using agar plug diffusion method according to Egorov, (1985). The test bacteria and fungi were obtained from The Regional center for Mycology and Biotechnology, AL-Azhar University, Egypt. 
Secondary screening of the isolated microorganisms for Antimicrobial activity by agar well diffusion method:-

Sixteen isolates were selected for secondary screening in small scale submerged fermentation system. Two hundred milliliter of Starch Casein Broth was dispensed in to $500 \mathrm{ml}$ Erlenmeyer Flask, to which a loop full of six days grown isolates were inoculated and incubated on a platform shaker at $100 \mathrm{rpm}$ at room temperature for 6 days according to (Remya and Vijayakumar, 2008; Dhanasekaran et al., 2009). were used agar well diffusion method was used to determination size of inhibition zone against five test microorganisms Bacillus subtilis NRRL B 543, Staphylococcus aureus ATCC 29213, Escherichia coli ATCC 25922, Candida albicans MTCC183 and Aspergillus niger NRRL 595.

\section{Identification of selected isolates:-}

The cultural, morphological and physiological characteristics of the selected isolates were studied using all the media and methods of International Streptomyces Project (ISP) as described by Shirling and Gottlieb (1966). Identification was carried out using the keys suggested by Buchanan and Gibbson (1974), Williams et al. (1989) and Hensyl (1994).

\section{Studies concerning the phylogenetic characteristic:-}

The locally isolated actinomycete was grown for 7 days on a starch agar slant at $30^{\circ} \mathrm{C}$. Two milliliter of a spore suspension was inoculated into starch nitrate broth and incubated for 3 days on an incubator shaker at $200 \mathrm{rpm}$ and $30^{\circ} \mathrm{C}$ to form a pellet of vegetative cells. The preparation of the total genomic DNA was conducted in accordance with the methods described by Sambrook et al. (1989). The PCR amplification of 16S rDNA gene of the local actinomycete strain was conducted using two primers: F27 with a sequence 5-AGA GTT TGA TCM TGG CTCAG-3 and R1492 with a sequence 5-TACGGGYTACCTTGTTACGACTT-3. Purification of the PCR products and sequencing of the PCR products for the isolate under study were performed at the Sigma Company of Scientific Service (Cairo-Egypt).

Sequence data were analysed in the 'GenBank database' by using the BLAST program available on the National Center for Biotechnology Information website (www.ncbi.nlm.nih.gov). The unknown sequence was compared with all the sequences in the database to assess the DNA similarities. Multiple sequence alignment and molecular phylogeny were evaluated using BioEdit software (Hall 1999).

\section{Optimization of culture conditions affecting antimicrobial compound production:-}

The optimization studies for enhancing the antimicrobial activity were done in a series of experiments by using the approach of changing one variable at a time and keeping the other factors fixed at a specific set of conditions. At the end of each experiment, the antimicrobial activity was determined by measuring the inhibition zones after $24 \mathrm{~h}$. This work was done at the AL-Azhar Center for Fermentation 
Biotechnology \& Applied Microbiology, AL-Azhar University, Cairo, Egypt.

\section{Optimization of physical parameters:-}

This included optimization studies for the best medium, incubation period, temperature, $\mathrm{pH}$ and agitation speed. For selecting the best production medium, the test was done by carrying out the fermentation separately in different media i.e. starch casein nitrate (SCA) broth, tryptone yeast extract broth (ISP 1), yeast extract malt extract broth (ISP 2), modified soluble starch (MSS), and starch nitrate broth medium (SNB) (Suthindhiran et al., 2009). The value of the $\mathrm{pH}$ of the media was changed from 4 to 9 to arrive on the optimum $\mathrm{pH}$ for maximum production. The temperatures used for optimization were $25,28,31,34$ and $40^{\circ} \mathrm{C}$. Flasks were incubated in shaker incubator at $100 \mathrm{rpm}$ for 6 to 10days (Saadoun et al., 2008).

\section{Optimization of biochemical parameters:-}

The biochemical parameters taken for optimization were the different sources of carbon, nitrogen, different $\mathrm{NaCl}$ and phosphate concentrations. Different carbon source were studded such as glucose, sucrose, maltose, glycerol and starch were supplemented separately to a final concentration of $1 \%(\mathrm{w} / \mathrm{v})$. While the tested nitrogen sources malt extract, yeast extract, potassium nitrate, ammonium sulphate, and peptone were supplemented to a final concentration of $0.2 \%$. For the effect of different $\mathrm{NaCl}$ concentration, the broth medium was supplemented with different concentration of $\mathrm{NaCl}$ as $0.0,0.5,1.0,1.5,2.0$ and $2.5 \%$ (w/v) individually. While the best concentration of phosphate determined by using different concentration as 0 , 2.0, 4.0, 6.0 and 8.0 (g/l) individually. The best potassium nitrate concentration was determined by using different potassium nitrate concentration as 0.2, 0.4, 0.6, 0.8 and $1 \%$ and for the best starch concentration determined by testing at 1.0, 1.5, 2.0, 2.5 and $3 \%$ (Usha et al., 2010).

\section{Extraction and purification of antimicrobial agents:-}

The antimicrobial agent produced in the optimized medium by the selected isolate was extracted from the filtrate by the solvent extraction method of Maneerat and Dikit (2007). Five liters of culture broth was used to extract and purify the antimicrobial agent. The culture was first centrifuged for $25 \mathrm{~min}$ at $5000 \mathrm{rpm}$ at $4^{\circ} \mathrm{C}$. The crude material was extracted by mixing with an equal volume of ethyl acetate and mixed in the separator funnel, shaken vigorously and allowed to stand for $30 \mathrm{~min}$. The aqueous layer formed at the bottom of the separator funnel was removed and the white layer of antimicrobial agent just above the aqueous layer was collected in a glass Petri dish and left in the oven at $40-45^{\circ} \mathrm{C}$ until dry to evaporate the pre-coated silica gel TLC plates. The concentrated extract was run on silica TLC plates using ethyl acetate: toluene: formic acid in varying ratios: 5: 4: 1 (Sherma and Fried 1996).

The TLC plates were examined under a UV lamp at a wavelength of 254-365 $\mathrm{nm}$. All spots from the about 20 TLC plates were scraped and examined for antimicrobial activity. The active compound was dissolved in a minimum amount of methanol and examined for purity on TLC. Finally, the purified compound was 
collected and used for characterization purposes. The compound separated by TLC was collected by scraping and it was preserved in a clean screw-capped glass vial as dried powder (Fernandes et al., 2007).

\section{Minimum inhibitory concentration MIC:-}

The minimum inhibitory concentrations (MIC) of antimicrobial compound of actinomycete were determined by well diffusion method. The antimicrobial compound was dissolved in methanol different concentrations of extracts was diluted using a twofold serial dilution to give final testing concentrations Different weights of the purified antimicrobial compound range from $1.95 \mu \mathrm{g}$ up to $1000 \mu \mathrm{g} / \mathrm{mL}$ were applied. The plates were incubated $24-48 \mathrm{~h}$ at $37{ }^{\circ} \mathrm{C}$ for bacteria and $48-72 \mathrm{~h}$ at $28{ }^{\circ} \mathrm{C}$ for fungi, the plates were examined (Bordoloiet al., 2001).

Mode of action of antimicrobial agent produced by S. griseoplanus (S1SHA1) on the test microbial strains by Transmission Electron Microscopy (TEM):-

The effect of purified antimicrobial compound produced by Streptomyces griseoplanus on bacterial and yeast cells were evaluated by electron microscopy. Both Staphylococcus aureus ATCC 29213, Escherichia coli ATCC 25922 and Candida albicans MTCC183 were grown in Nutrient Agar for bacteria and Sabouraud Dextrose Agar for yeast at $37^{\circ} \mathrm{C}$. The cultures were collected during the exponential phase by centrifugation at $9000 \mathrm{rpm}$ for 7 minutes and were then re-suspended in peptone water. Samples were treated with purified compound at $62.5 \mu \mathrm{g} / \mathrm{ml}$ and were incubated at $37^{\circ} \mathrm{C}$ for 12 hour. Samples were then collected by centrifugation at $9000 \mathrm{rpm}$ for 7 minutes and were fixed with $2 \%$ of glutaraldehyde in $0.1 \mathrm{M}$ sodium cacodylate, $\mathrm{pH} 7.4$ for 2 hours at $4^{\circ} \mathrm{C}$. The cells were collected and washed twice with PBS buffer, and were then postfixed in $1 \%$ osmium tetroxide for 1 hour at $4^{\circ} \mathrm{C}$. The cells were dehydrated through as ascending ethanol series solutions and followed by propylene oxide treatment. The cells were embedded, cut and stained with $2 \%$ uranyl acetate and lead citrate. The sections were observed using Transmission Electron Microscopy TEM (JEOL 1010, Japan) at the Regional center for Mycology and Biotechnology, AL-Azhar University, Egypt.

\section{Cytotoxicity evaluation using viability assay:-}

The cytotoxicity assay of Mosmann (1983) was performed as follows: the normal MRC-5 cell line cells were seeded in 96-well plate at a cell concentration of $5 \times 10^{4}$ cells per well in $100 \mu \mathrm{L}$ of growth medium. Fresh medium containing different concentrations of the test sample was added, after $24 \mathrm{~h}$ of seeding. The Microtiter plates were incubated at $37{ }^{\circ} \mathrm{C}$ in a humidified incubator with $5 \% \mathrm{CO}_{2}$ for a period of $24 \mathrm{~h}$. Three wells were used for each concentration of the purified compound. Control cells were incubated without test sample and with or without DMSO. Then, the viable cells yield was determined by a MTT colorimetric assay. Treated samples were compared with the cell control in the absence of the tested compound. All experiments were carried out in triplicate. The cellular cytotoxic effect of the tested compound was calculated. The percentage of viability was calculated as 
$\left[\left(\mathrm{OD}_{\mathrm{t}} / \mathrm{OD}_{\mathrm{c}}\right)\right] \times 100 \%$

Where: $\mathrm{OD}_{\mathrm{t}}$ is the mean optical density of wells treated with the tested sample and $\mathrm{OD}_{\mathrm{c}}$ is the mean optical density of the untreated cells. The $50 \%$ cell cytotoxic concentration $\left(\mathrm{CC}_{50}\right)$ is the concentration required to cause toxic effects in $50 \%$ of intact cells that was estimated from graphic plots of the dose response curve for each concentration using Graphpad Prism software (San Diego, CA. USA).

\section{Results and Discussion:-}

The increase in the frequency of multi- resistant pathogenic bacteria is created an urgent demand in the pharmaceutical industry for more rational approaches and strategies to the screening of new antibiotics with a broad spectrum of activity, which resist the inactivation processes exploited by microbial enzymes (Saadoun and Gharaibeh, 2003; Motta et al., 2004). The species belonging to the genus Streptomyces constitute $50 \%$ of the total population of soil actinomycetes and $75-80 \%$ of the commercially and medicinally useful antibiotics have been derived from this genus (Mellouli et al., 2003). However, screening and isolation of promising actinomycetes with potential antibiotics is still a thrust area of research and it is suggested that the exploration of materials from different areas and habitats have a vital role to play in the search for new microbes and novel metabolites and is urgent to counter the threats posed by the fast emerging phenomenon of antibiotic resistance (Saadoun and Gharaibeh, 2003; El-Naggar et al., 2006).

Thus, in the present work, different microorganisms were isolated and then screened with regard to their potential to generate antibiotics. The different soil localities at Al-Sharqia and Qaliobia governorate from which, isolation of different organisms was carried out. Also, several studies revealed that the microflora present in the rhizosphere can produce antagonistic molecules that will inhibit or kill the pathogens present (Rondon et al., 1999; Jaben et al., 2004).

\section{Primary screening of the isolated microorganisms for Antimicrobial activity:-}

Seventy six isolates of microorganisms were obtained from soil samples and screened for antimicrobial activity against four test organism Bacillus subtilis NRRL B 543, Staphylococcus aureus ATCC 29213, Escherichia coli ATCC 25922 and Candida albicans MTCC183. Inhibition zones indicate that microorganisms produce antimicrobial compound after $24 \mathrm{hrs}$ of incubation.

Sixteen out of seventy six actinomycetes isolates showed noticeable antimicrobial activities against Gram positive and Gram negative bacteria and yeast by agar plug diffusion method. Actinomycetes from Anshas El Raml soil sediments showed strong antimicrobial activity against the panel of pathogen. But few of the strains have not antimicrobial activity. 
Secondary screening of the isolated microorganisms for Antimicrobial activity by agar well diffusion method:-

Based on the results of primary screening, it was found that 16 strains suppressed the test microorganisms in a wide range. The results of ethyl acetate crude extracts of 16 actinomycetes for antimicrobial activities were screened against 5 test microorganisms as presented in (Table 1).

Moreover, only five strains viz S1SHA1, SHSA9, SHSA29, SHSA49 and SHSA66 were confirmed for their higher antimicrobial activity (Table1). The highest antimicrobial activity was seen in the strain S1SHA1.

Among the tested actinomycetes, the ethyl acetate extract of the actinomycetes strain S1SHA1 showed 38, 37, 35, 32 and $35 \mathrm{~mm}$ zone of inhibition broad spectrum of antimicrobial activity against Bacillus subtilis NRRL B 543, Staphylococcus aureus ATCC 29213, Escherichia coli ATCC 25922, Candida albicans MTCC183and Aspergillus niger NRRL 595, respectively.

Table (1): Antimicrobial activity of ethyl acetate extract obtained from the selected sixteen actinomycetes and tested using agar well diffusion method.

\begin{tabular}{||c|c|c|c|c|c|c||}
\hline \multirow{2}{*}{ No, } & \multirow{5}{*}{ Tested isolates } & \multicolumn{5}{|c||}{ Zone of inhibition (mm) } \\
\cline { 3 - 7 } & & Bubtilis & S. aureus & E. coli & C. albicans & A. niger \\
\hline 1 & S1SHA1 & 38 & 37 & 35 & 32 & 35 \\
\hline 2 & S2SHA4 & 21 & 25 & 10 & 28 & 14 \\
\hline 3 & S2SHA6 & 32 & 28 & 29 & 32 & 31 \\
\hline 4 & S3SHA2 & 15 & 18 & 14 & 12 & 14 \\
\hline 5 & S3SHA5 & 19 & 14 & 30 & 19 & 18 \\
\hline 6 & S3SHA6 & 13 & 11 & 17 & 11 & 00 \\
\hline 7 & S6QA3 & 11 & 14 & 15 & 15 & 19 \\
\hline 8 & S6QA4 & 25 & 17 & 31 & 29 & 28 \\
\hline 9 & S7QA1 & 10 & 20 & 12 & 15 & 27 \\
\hline 10 & S7QA6 & 17 & 13 & 11 & 13 & 00 \\
\hline 11 & S7QA7 & 13 & 15 & 15 & 21 & 29 \\
\hline 12 & S9SHA3 & 29 & 33 & 30 & 32 & 32 \\
\hline 13 & S10SHA2 & 16 & 13 & 19 & 23 & 19 \\
\hline 14 & S12SHA1 & 16 & 14 & 10 & 11 & 00 \\
\hline 15 & S13SHA1 & 27 & 30 & 32 & 28 & 30 \\
\hline 16 & S14SHA4 & 12 & 16 & 11 & 17 & 25 \\
\hline
\end{tabular}




\section{Taxonomic characterizations of the actinomycete isolate S1SHA1:-}

Micro-morphological study of actinomycete isolate, S1SHA1 using a scanning electron microscope (JSM-5500) revealed that the spore chain was composed of elongate shaped spores with a smooth surface (Fig. 1). The data represented in Table 2 illustrate the cultural characteristics of the actinomycete isolate S1SHA1grown on different ISP media. The aerial hyphae of the isolate were grey with brown substrate mycelia but no diffused pigment was recorded. Carbon and nitrogen utilization, degradation test, sensitivity assay, tolerance to $\mathrm{NaCl}$, growth $\mathrm{pH}$ and growth temperature were studied. The entire hydrolysate cell of this strain contained LL-diaminopimelic acid but no characteristic sugars could be detected (Table 3). Cell wall composition analysis is one of the main methods that can be employed to identify the chemotaxonomic characteristics of Streptomyces.

\section{S rRNA gene sequencing and phylogenetic analysis:-}

To confirm the identification of the actinomycete isolate, the 16S rRNA sequence of the selected S1SHA1 isolate was compared with the sequence of Streptomyces sp. through multiple sequence alignment. Experimental analysis of the PCR amplification was studied through agarose gel electrophoresis. Figure 2shows the multiple sequence alignment, which showed that this isolate was close to Streptomyces griseoplanus NRRL- ISP5009 by query $93 \%$.

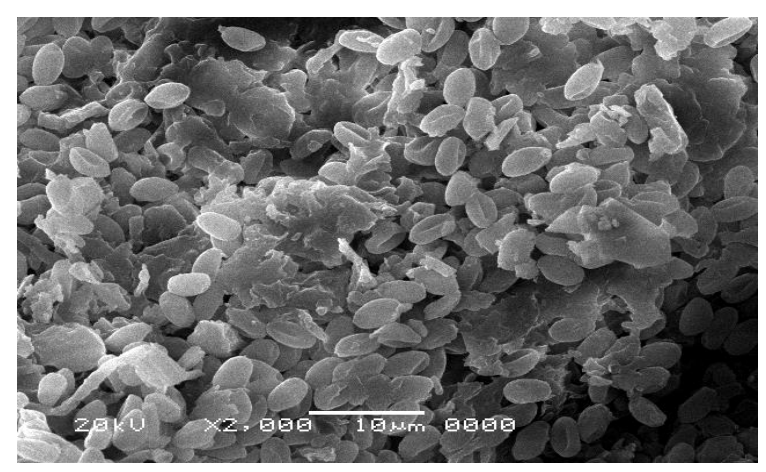

Figure (1): Scanning electron micrograph of Streptomyces griseoplanus, (S1SHA1) grown on starch nitrate casein agar medium for 4 days $(X 5,000$; bar $5 \mu \mathrm{m})$. 


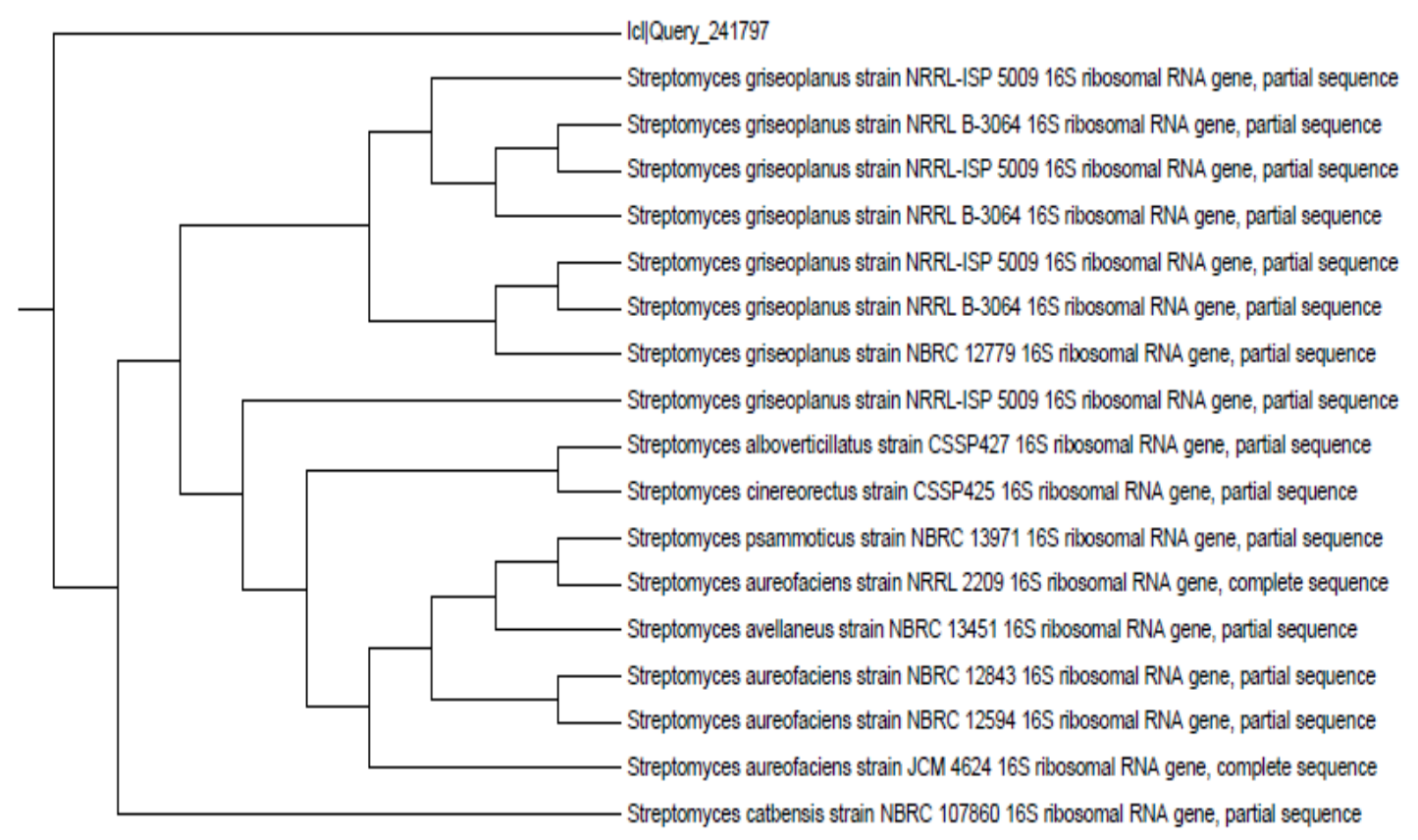

Figure (2): 16S rRNA gene tree showing the phylogenetic relationship neighbor- joining method between strain S1SHA1 and other known sequence of Streptomyces sp.

Table (2): Cultural and physiological characteristics of selected isolate S1SHA1.

\begin{tabular}{|c|c|c|}
\hline Medium & Growth & Substrate mycelium \\
\hline Yeast-malt extract agar (ISP 2) & Good & Brown 59 \\
\hline Oat meal agar (ISP 3) & Good & Dark yellow \\
\hline Inorganic salts-starch agar (ISP 4) & Good & Dark brown 72 \\
\hline Glycerol-asparagine agar (ISP 5) & Moderate & Brown 59 \\
\hline Peptone yeast extract iron agar (ISP 6) & Good & Light brown \\
\hline Tryptone yeast extract broth (ISP 1) & Moderate & Yellow brown \\
\hline
\end{tabular}


Table (3): The morphological, physiological and biochemical characteristics of the selected isolate S1SHA1.

\begin{tabular}{|c|c|c|c|}
\hline \multicolumn{4}{|c|}{ Chemotaxonomic analysis } \\
\hline \multicolumn{2}{|c|}{ Cell wall hydrolysis for: } & \multicolumn{2}{|c|}{ Utilization of nitrogen source } \\
\hline $\begin{array}{c}\text { Diaminopimelic acid } \\
\text { (DAP) }\end{array}$ & LL-DAP & L-Valine & - \\
\hline Sugar pattern & ND & L-Methionine & + \\
\hline \multicolumn{2}{|c|}{ Morphological characteristics } & L-Phenylalanine & + \\
\hline Spore chains & Elongate & L-Histidine & + \\
\hline Spore surface & Smooth & L-Asparagine & + \\
\hline Spore mass colour & Gray & L-Serine & + \\
\hline Substrate mycelialcolour & Brown & L-Leucine & + \\
\hline $\begin{array}{c}\text { Diffusible pigment } \\
\text { produced }\end{array}$ & - & L-Proline & + \\
\hline \multicolumn{2}{|c|}{ Biochemical characteristics } & L-Aspartic acid & + \\
\hline Lipolysis & + & \multicolumn{2}{|c|}{ Utilization of carbon source } \\
\hline Gelatin hydrolysis & - & Glucose & + \\
\hline Nitrate reduction & + & Raffinose & - \\
\hline Starch hydrolysis & + & Xylose & + \\
\hline Catalase & + & Lactose & + \\
\hline \multicolumn{2}{|c|}{ Sensitivity assay } & Arabinose & + \\
\hline Growth pH (5-10) & + & Cellobiose & - \\
\hline $\begin{array}{l}\text { Growth temperature }(15- \\
\left.440^{\circ} \mathrm{C}\right)\end{array}$ & + & D-Mannose & + \\
\hline $\begin{array}{c}\text { Growth with } \mathrm{NaCl}(4-9 \% \text {, } \\
\text { w/v) }\end{array}$ & + & D-Galactose & - \\
\hline L-Cysteine & + & Starch & + \\
\hline
\end{tabular}

\section{Optimization of physical and biochemical parameters for antimicrobial production by Streptomyces griseoplanusS1SHA1:-}

Optimization of various physical parameters including different types of media, incubation period, temperature, $\mathrm{pH}$ and agitation speed were determined.The 
difference in activity of antimicrobial agent in different types of media. The results illustrated in Fig. 3 indicate that SCA was the best production medium, giving a maximum inhibition zone on the test organisms followed by SNB medium (Fig. 3). Also, the difference in activity of the antimicrobial activity with different incubation periods culture conditions showed that it reaching its maximum activity after 7 day (Fig. 6) there are no significant variation shown in the antimicrobial activity at range 7 - 9 days. Streptomyces griseoplanus NRRL-ISP 5009, S1SHA1 produced antimicrobial agents with highest activity at $\mathrm{pH} 7$ while decreased gradually at danger $\mathrm{pH}$ value (Fig. 4). The temperature was one of the critical parameters that has been controlled in the bioprocess. The difference inactivity of antimicrobial compound at different incubation temperatures was the highest value when the isolate grew at $28{ }^{\circ} \mathrm{C}$ as shown in (Fig. 5). On the other hand, the antimicrobial agent activity production was not severely affected by increasing the temperature up to $40^{\circ} \mathrm{C}$. Agitation plays a very important role in the production of antimicrobial compound, which facilitates the oxygen transfer from the gas phase to the aqueous phasein the present study the highest antimicrobial compound production was obtained at an agitation speed $150 \mathrm{rev}$ min-1(Fig. 7). The results obtained for demonstrated that the optimal carbon source for antimicrobial compound production was starchwith best concentration $1.5 \%$ (Fig. 8 and 13). While the best nitrogen source for highest production of antimicrobial compound is potassium nitrate with best concentration $0.4 \%$ (Fig. 9 and 12), were the optimal $\mathrm{NaCl}$ concentration for production of antimicrobial compound was $2 \mathrm{~g} / \mathrm{l}$ (Fig. 10).

\section{Extraction and purification of the crude antimicrobial agent:-}

The antimicrobial compound produced by S. griseoplanus NRRLISP5009, S1SHA1 was extracted with equal volume of ethyl acetate which resulted in the extraction of a brown colour precipitate. The TLC analysis performed for the extract showed the presence of eleven bands after charring with ethyl acetate: toluene: formic acid with ratio 5:4: 1 as the best mobile phase. The eleven bands were observed under UV light, the spot with Rf value of 0.36Showedthe highest inhibition zone. The most active compound was purified through a preparative TLC. The purity of the compound was checked by performing TLC analysis which showed asingle spot at an Rf value of 0.36 .

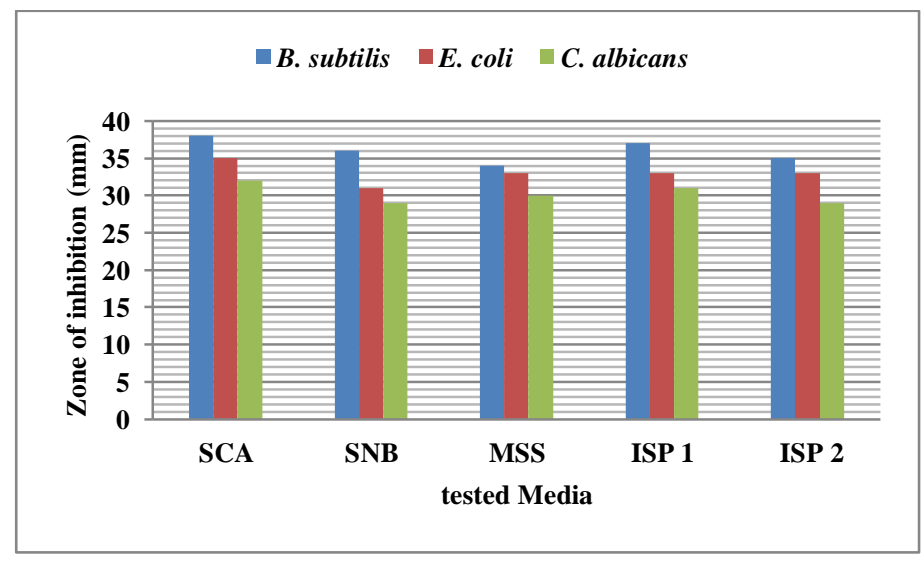

Figure (3): Effect of various media. 


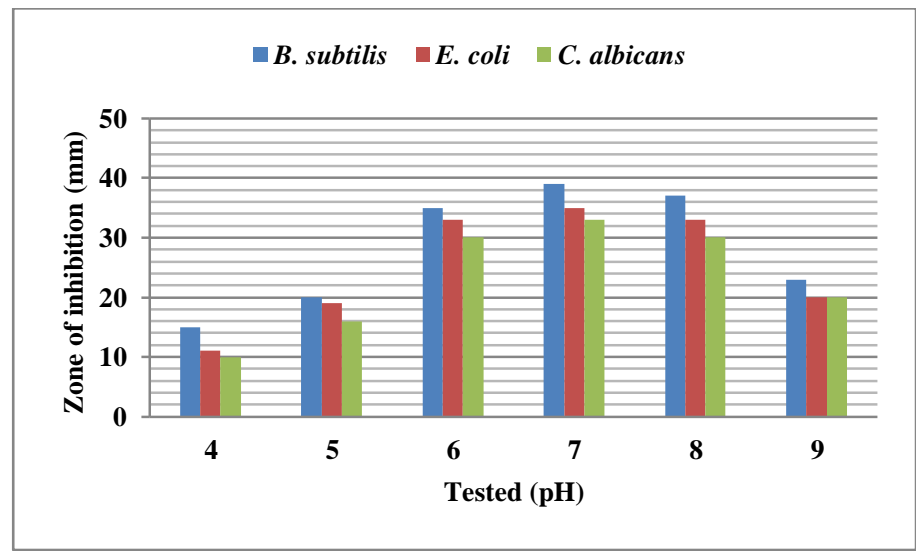

Figure (4): Effect of $\mathrm{pH}$.

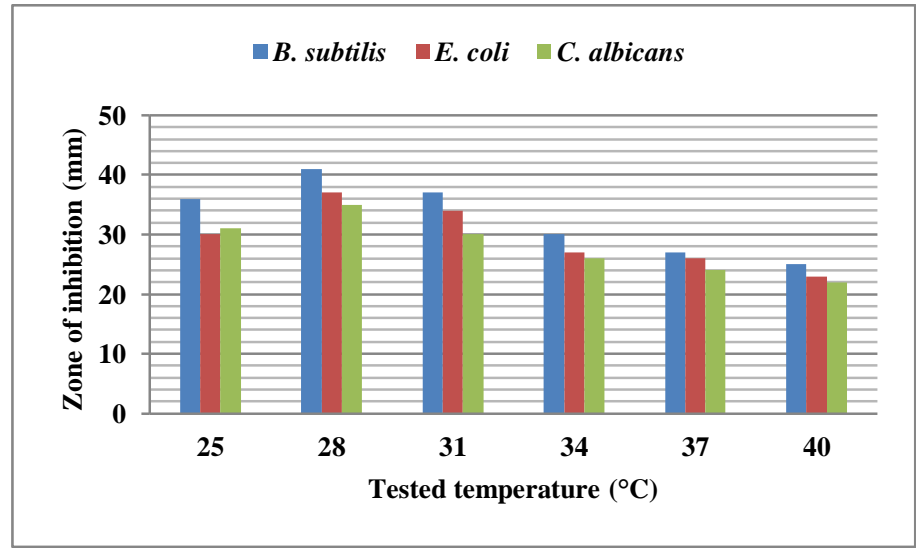

Figure (5): Effect of temperature.

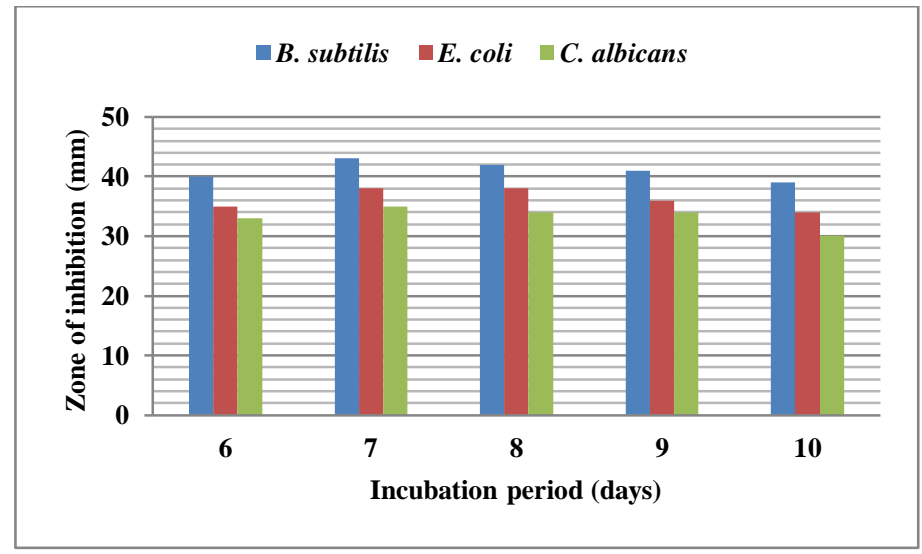

Figure (6): Effect of incubation period. 


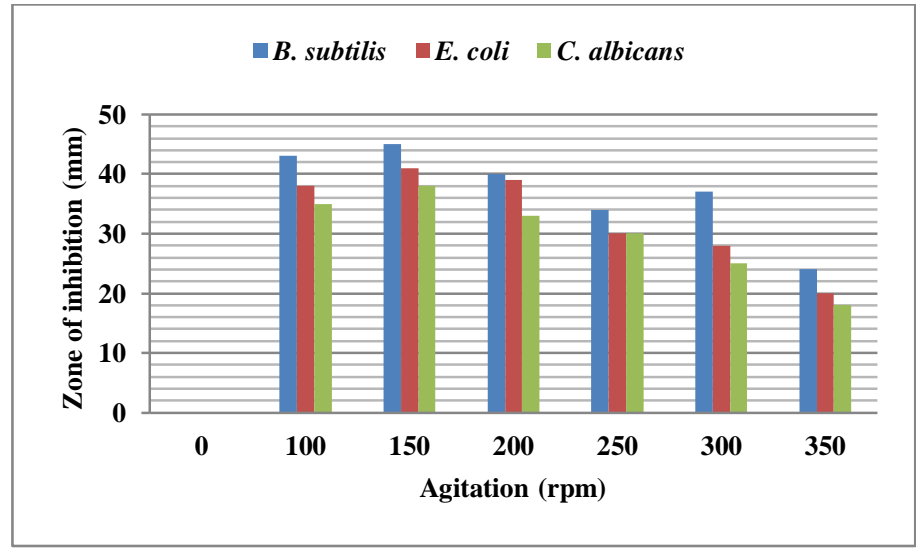

Figure (7): Effect of agitation.

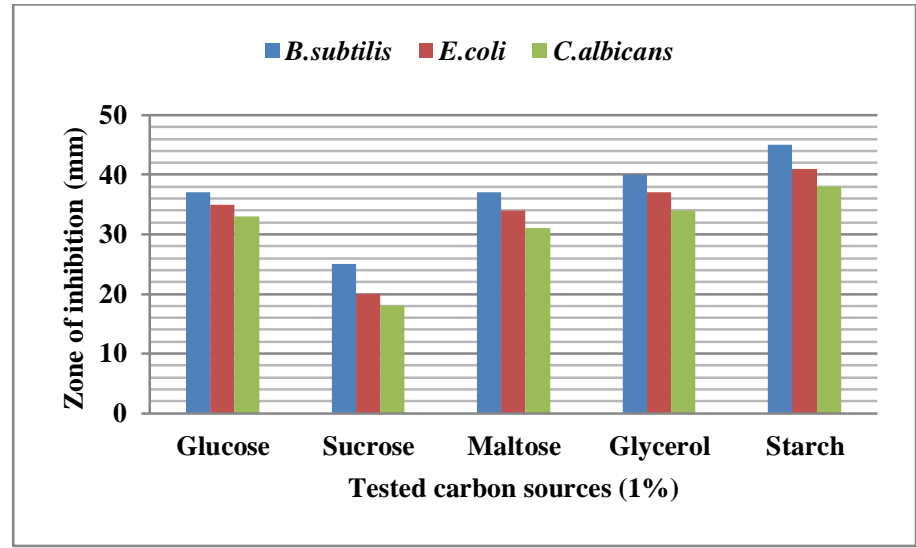

Figure (8): Effect of different carbon sources.

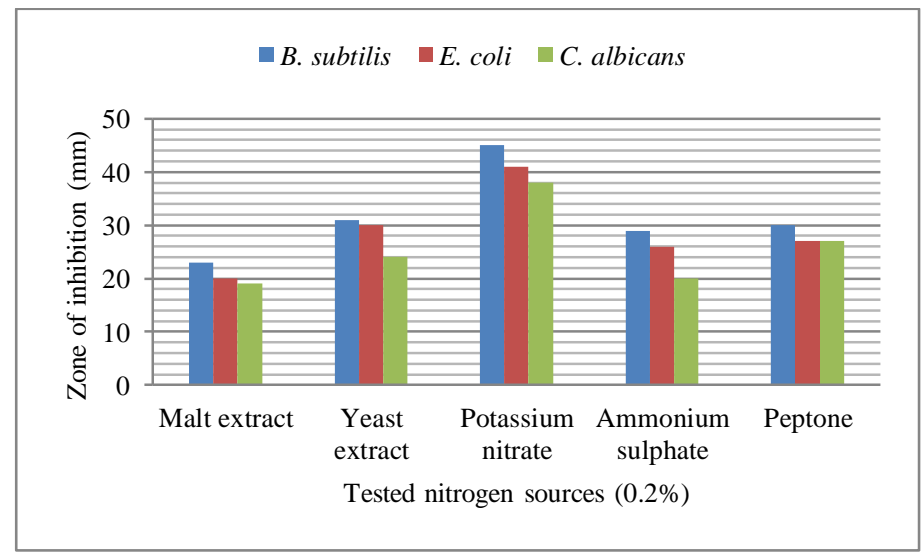

Figure (9):Effect of different nitrogen sources. 


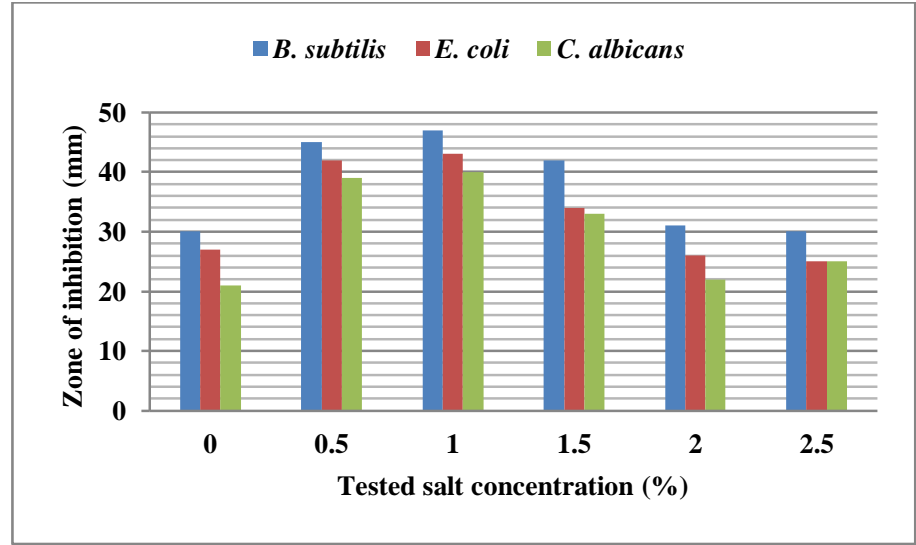

Figure (10): Effect of different salt concentration.

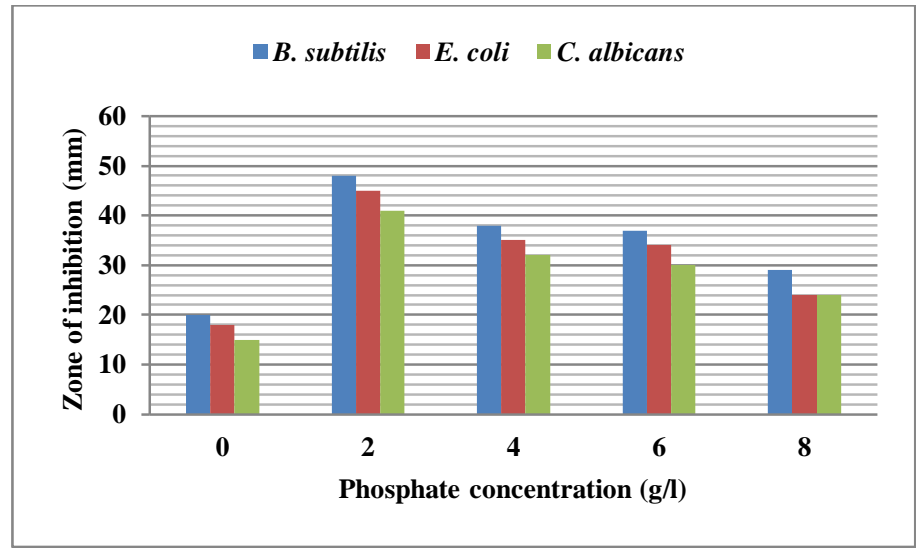

Figure (11): Effect of different phosphate concentration (K2 HPO4).

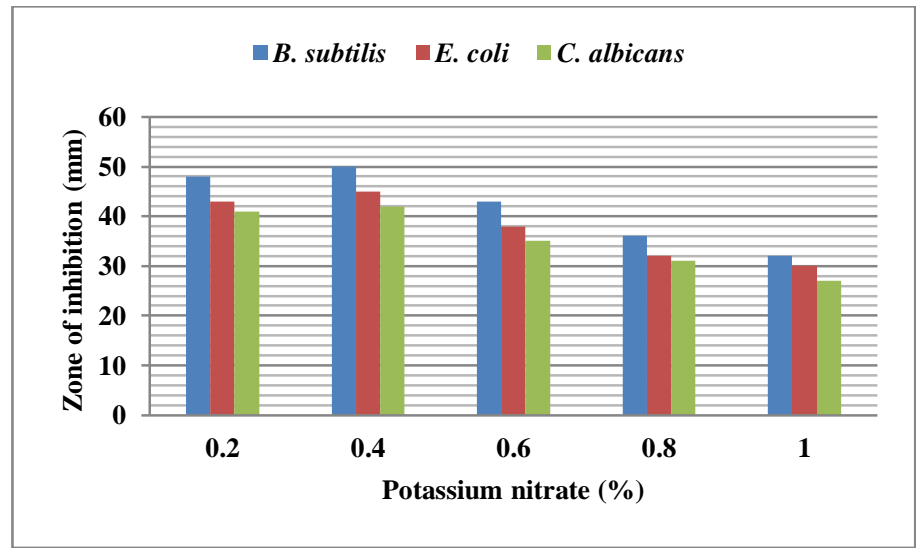

Figure (12): Effect of different potassium nitrate concentration. 


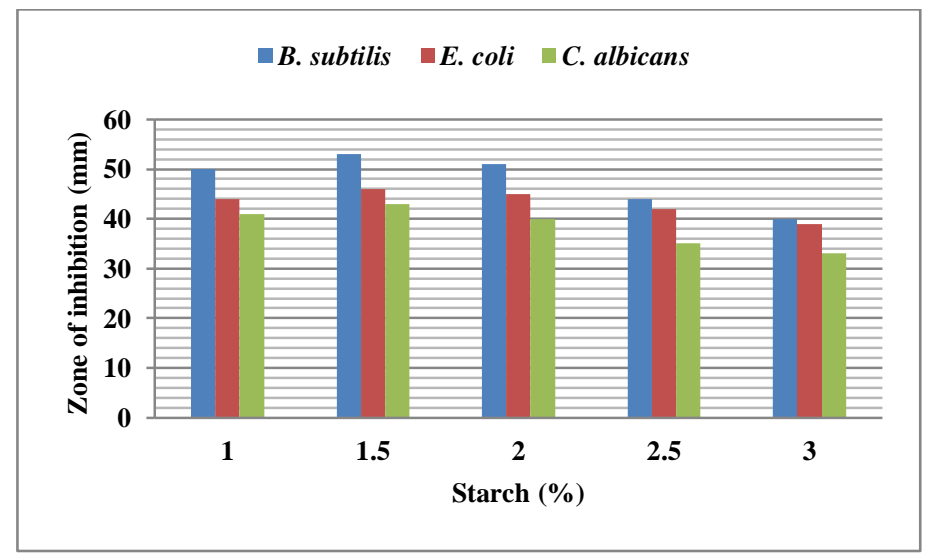

Figure (13): Effect of different Starch concentration

\section{Determination of the MIC of the purified compound}

MIC values of the antimicrobial compound from S1SHA1 against different target organisms were determined by agar well diffusion. Bacillus subtilis NRRL B 543 and Klebsiella pneumonia were the most sensitive to antimicrobial compound produced by S1SHA1 followed by other bacteria (Table 4).

Table (4): MIC values of the antimicrobial compound from Streptomyces griseoplanus against different pathogenic test organisms.

\begin{tabular}{||c|c|}
\hline Test organism & MIC $(\mu \mathrm{g} / \mathrm{ml})$ \\
\hline Bacillus subtilis NRRL B 543 & 62.5 \\
\hline Staphylococcus aureus ATCC 29213 & 62.5 \\
\hline Escherichia coli ATCC 25922 & 62.5 \\
\hline Pseudomonas aeruginosa ATCC & 62.5 \\
\hline Candidaalbicans MTCC183 & 62.5 \\
\hline Aspergillusniger NRRL 595 & 125 \\
\hline
\end{tabular}

The MIC is not a constant for a given agent, because it is affected by the nature of the test organism used, the inoculum size, and the composition of the culture medium, the incubation time, and aeration (Pandey et al., 2004).

It is important to obtain a full characterization of an antimicrobial compound metabolite before it can be put into use since its behavior under different conditions will determine its application and ultimate usefulness (Betina, 1964; Porter, 1971; Simone et al., 1998).

\section{Effect on Ultrastructure of Bacterial and yeast Cells:-}

The effect of purified antimicrobial compound on bacterial cell structure was 
tested using transmation electron microscopy on Gram-negative tested bacteria Escherichia coli ATCC 25922, Gram-positive tested bacteria Staphylococcus aureus and yeast Candida albicans MTCC183

The untreated Staphylococcus aureus ATCC 29213 appeared cocci that displayed normally dividing cells with sharp delineation between cell wall, cytoplasmic membrane and the cytoplasm (Fig. 14). After incubation of the bacterial cells with purified antimicrobial compound, dramatic cellular alterations became visible on electron microscopic image (Fig. 14). The treated cells appeared oblong; edges become abnormal, elongated. Cell wall disrupted and exhibited thickened in some parts and breakdown in other due to leakage of cytoplasm.

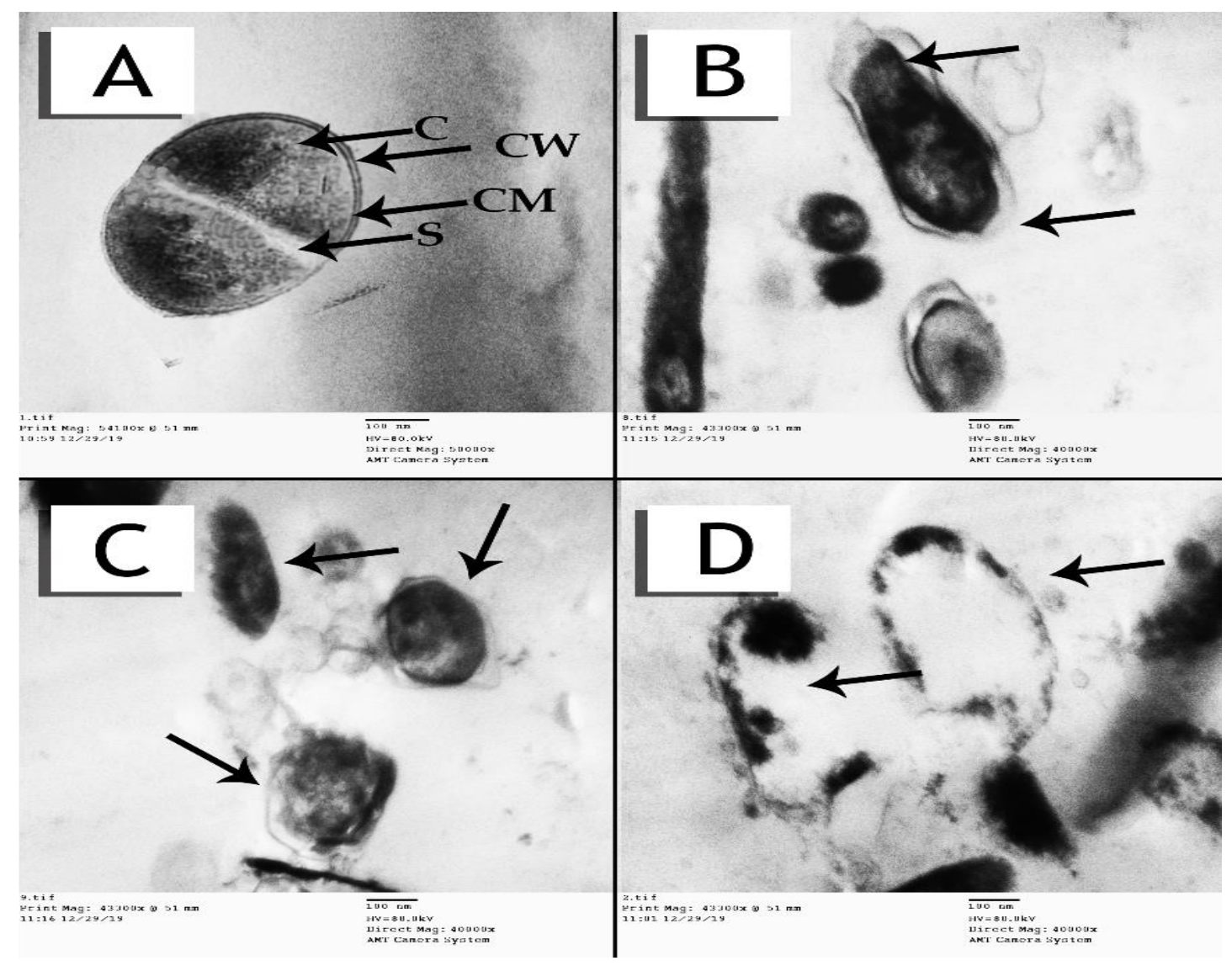

Figure (14): TEM microphotographs of Staphylococcus aureus. A: without treatment. B, C\&D: treated with purified antimicrobial compound with concentration $62.5 \mu \mathrm{g} / \mathrm{ml}$. Where, S: septum, CW: cell wall, CM: cell membrane, C: cytoplasm.

Escherichia coli ATCC 25922appeared short rods in TEM micrograph of untreated cells and showed a continuous thin smooth cell wall, cell membrane and nuclear material (Fig. 15). When subjected of Escherichia coli cells to purified antimicrobial compound, bacterial cells lysed rapidly, so cells appeared as very long threads. Cytoplasm shrinked leaving cell wall, while other cells appeared metamorphosed, cytoplasm lost its even distribution and showed clumping of intracellular materials. Cell wall was lost uniformity and leading to cell wall rupture and even strong damage in many areas with thickened appearance more pronounced 
at polar-regions (Fig. 15).

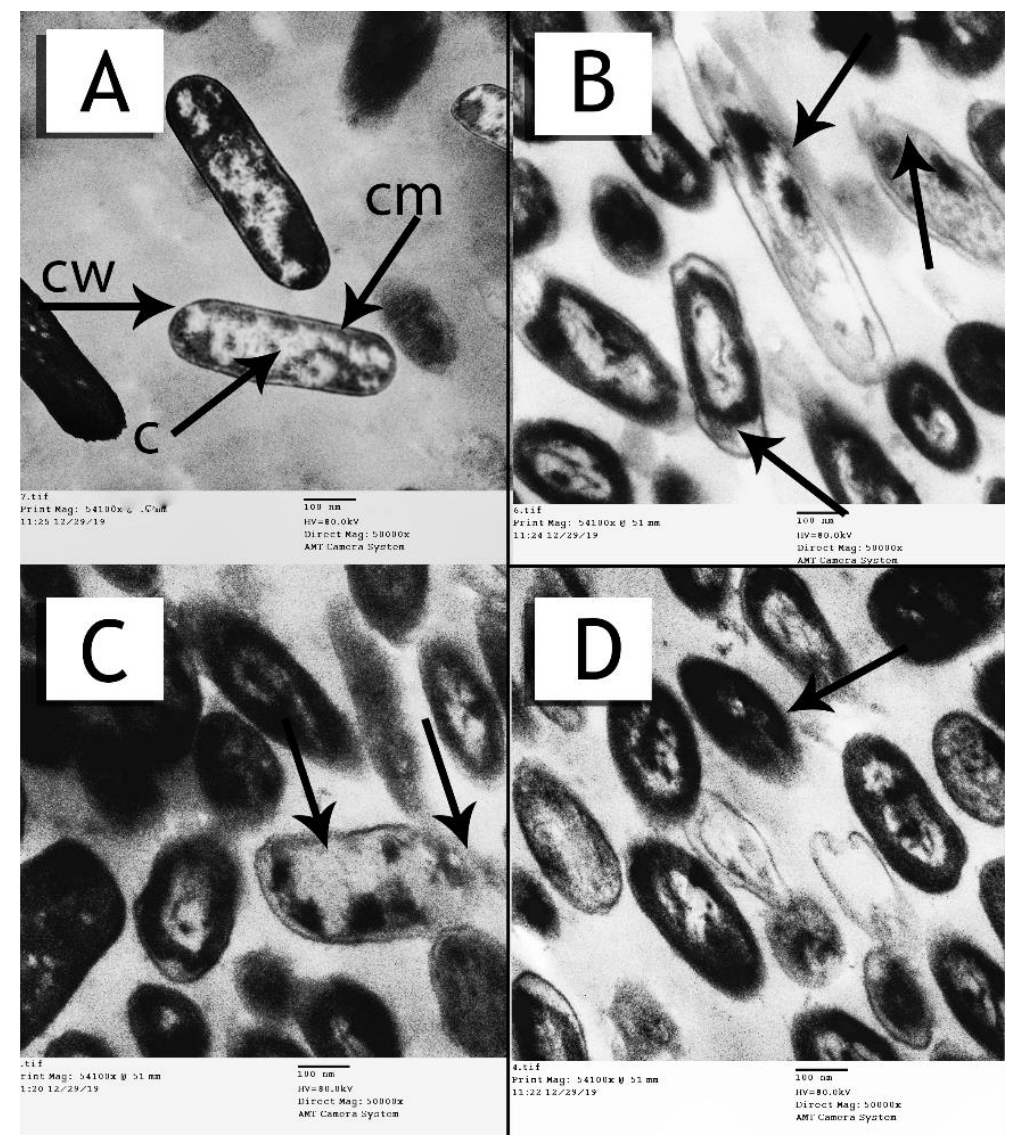

Figure (15): TEM microphotographs of Escherichia coli. A: without treatment. B, C\&D: treated with purified antimicrobial compound with concentration $62.5 \mu \mathrm{g} / \mathrm{ml}$. Where, CW: cell wall, CM: cell membrane, C: cytoplasm.

Candida albicans MTCC183in TEM micrograph of untreated cells and showed The cytoplasm of control cells appeared homogeneous containing a nucleus, vesicle and mitochondria, surrounded by a defined cell membrane and regular cell wall with a clear periplasm region(Fig. 16). When subjected of Candida albicans MTCC183 cells to purified antimicrobial compound, the inner organelles were completely discomposed and even cell membrane and wall were deeply affected and look like undulant. Yeast cells were found collapsed which followed by an outflow of the cytoplasmic component (Fig. 16). 


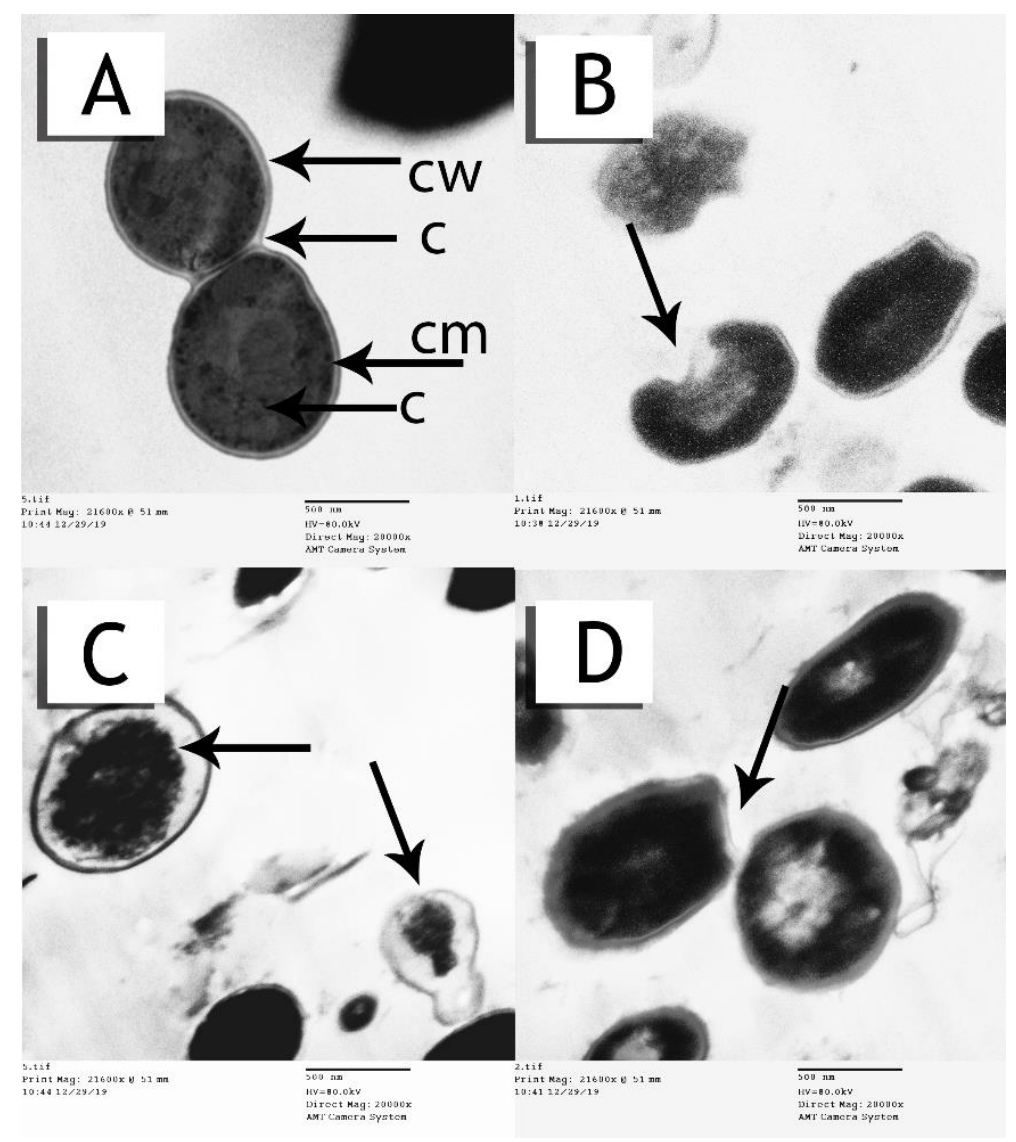

Figure (16): TEM microphotographs of Candida albicans. A: without treatment. B, C\&D: treated with purified antimicrobial compound with concentration $62.5 \mu \mathrm{g} / \mathrm{ml}$. Where, CW: cell wall, CM: cell membrane, C: cytoplasm.

\section{Cytotoxic activity of the purified compounds:}

The cytotoxic effect of the purified compounds was evaluated against normal lung fibroblast cell line (MRC-5) cells using MTT assay. The estimated $\mathrm{CC}_{50}$ was at $1000 \mu \mathrm{g} / \mathrm{ml}$ which was 15 more than the determined MIC. Interestingly, no cytotoxic effects were observed for the compound when tested even at high concentrations (Fig. 17).

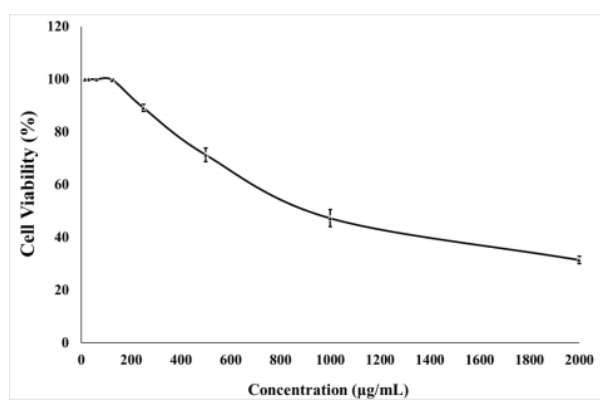

Figure (17): Dose response curve showing the cytotoxic activity of the purified compound obtained from $S$. griseoplanus S1SHA1 on the normal lung fibroblast cell line (MRC-5) cells using MTT assay. 


\section{Conclusion}

The need for new, safe and more effective antimicrobial agent is a major challenge to the pharmaceutical industry today, especially with the increase in opportunistic infections in the immune compromised host. The result obtained in the present investigation indicated that $S$. griseoplanus S1SHA1 produced a non-protein, non toxic antimicrobial agent. Hence this antibiotic is a good drug against various microorganisms. We also further propose that the actinomycetes even today are a source for discovery of new antimicrobial antibiotics.

\section{Acknowledgment}

I would like to express my deeply indebted to Prof. Ayman A. Farrag, Professor of Microbiology and Director of Al-Azhar Center for Fermentation Biotechnology and Applied Microbiology, Faculty of Science, Al-Azhar University, Cairo for his scientific insights and support.

\section{REFERENCES}

AitBarka, E., Vatsa, P., Sanchez, L., Gaveau-Vaillant, N., Jacquard, C.,Klenk, H.-P., Clément, C., Ouhdouch, Y. and Van Wezel, G. P. (2016). Taxonomy, physiology, and natural products of Actinobacteria.Microbiol.Mol.Biol. Rev. 80, 1-43.

Arifuzzaman, M., Khatun, M. R. and, Rahman, H. (2010). Isolation and screening of actinomycetes from Sundarbans soil for antibacterial activity. Afr. J. Biotechnol. 9:4615-4619.

Awad, M.H., El-Shahed, K. Y. I. and E-Nakkadi, A. E. M. (2009). Isolation, Screening and Identification of Newly isolated soil Streptomycetes (Streptomycetes .NRC-35) for $\beta$ - Lactamase inhibitor production. J. W. Appli. Sci. 7: 637-646.

Bordoloi GN, Kumarim B, Guha A, Bordoloi M, Yadav RN, Roy MK, and Bora TC (2001). Isolation and structure elucidation of a new antifungal and antibacterial antibiotic produced by Streptomyces sp. 201.BiosciBiotechnolBiochem 65:1856-1858.

Buchanan, R.E. and Gibbson, N.E. (eds.) (1974). Bergey's Manual of Determinative Bacteriology, 8th edn. Baltimore:Williams and Wilkins.

Butler, MS, and Buss, AD. (2006). Natural products - The future scaffolds for novel antibiotics? BiochemPharmacol71(7):919-29.

Dhanasekaran, D., Thajuddin, N., and Panneerselvam, A. (2009). Distribution and Ecobiology of Antagonistic Streptomycetes from Agriculture and Coastal Soil in Tamil Nadu, India. J. Cult .Collec. 6:10-20. 
Egorov, N.S. (1985). Antibiotics, A scientific approach.Mir Publishers, Moscow.

El-Naggar MY, El-Assar SA, and Abdul-Gawad SM (2006). Meroparamycin production by newly isolated Streptomyces sp. strain MAR01: Taxonomy, fermentation, purification and structural elucidation. J Microbiol.; 44 (4):432438.

Fernandes, F.P.A.V., Arruda, I.R., Sanatos, A.F.A.B., Araujo,A.A., Maior, A.A.S. and Ximenes, E.A. (2007). Antimicrobial activity of surfactants produced by Bacillus subtilis R14 against multidrug-resistant bacteria.BrazJMicrobiol 38, 704-709.

Ghoneimy, E. A.,Wu, F.S. A. , Maie, A. Elkhawaga, Alassar, M.M. , Abdelaziz, M.M., and Elbatrawy, E. N. (2014). Evaluation Of Antimicrobial And Antioxidant Activities Of Some Edible Mushrooms.Egypt. Acad. J. Biolog. Sci., 6(2): $69-82$.

Goodfellow, M and Haynes, JA. (1984). Actinomycetes in marine sediments. In: Ortiz-Ortiz L, Bojalil LF, Yakoleff V, editors. Biological, Biochemical, and Biomedical Aspects of Actinomycetes. New York, USA: Academic Press. p. 453-72.

Hall, T.A. (1999). A user-friendly biological sequence alignment editor and analysis program for Windows 95/ 98/NT. Nucl Acids SympSer 41, 95-98.

Hensyl, W.R. (1994). Bergey's Manual of Systematic Bacteriology (9th edn) ed. Holt, J.G. and Williams, S.T. Baltimore: Williams and Wilkins.

Jaben N, Rasool S, Ahmad S, and Ajaz M, Saeed S. (2004). Isolation, identification and bacteriocin production by indigenous diseased plant and soil associated bacteria. Pakistan J Biol Sci.; 7:1893-1897.

LINDA H AL-Ghazali, L.H and OMRAN, R (2017). Optimization production conditions of antibacterial metabolite from Streptomyces sp. Asian $\mathrm{J}$ of Pharmaceutical and Clinical Research: 10, Issue 9, 2017.

Maneerat, S. and Dikit, P. (2007) Characterization of cellassociatedbioemulsifier from Myroids sp. SM1, a marine bacterium. J SciTechnol 29, 769-779.

Mellouli L, Mehdi RB, Sioud S, Salem M, and Bejar S (2003). Isolation, purification and partial characterization of antibacterial activities produced by a newly isolated Streptomyces sp. US24 strain. Res Microbiol.; 154: 345-52.

Miyadoh S. (1993). Research on antibiotic screening in Japan over the last decade: A producing microorganisms approach. Actinomycetologica; 9:100-6.

Mosmann T. (1983): Rapid colorimetric assay for cellular growth and survival: application to proliferation and cytotoxicity assays. J Immunol 
Methods. ;65(1-2):55-63.

Motta AS, Cladera-Olivera F, and Brandelli A (2004). Screening for antimicrobial activity among bacteria isolated from the Amazon Basin. Brazilian J Microbiol.; 35: 307-310.

Newman, DJ and Cragg, GM. (2007). Natural products as sources of new drugs over the last 25 years. J Nat Prod70 (3):461-77.

RemyaM., and R. Vijayakumar. (2008). Isolation and characterization of marine antagonistic actinomycetes from west coast of india. FactaUniversitatis Series: Med. Biol. 15: 13-19.

Richa, S. and Vivek, S. (2018). The role of actinobacteria in the production of industrial enzymes.New Future Dev. Microbial Biotechnol.Bioeng. (Ed. B. P. Singh, V. K. Gupta and A. K. Passari), pp. 165-177. London: ELSEVIER publisher.

Rondon M, Raffel S, Goodman R, Handelsman J (1999). Toward functional genomics in bacteria: analysis of gene expression in Escherichia coli from a bacterial artificial chromosome library of Bacillus cereus. Microbiol.; 96: 6451-6455.

Saadoun I, and Gharaibeh R (2003). The Streptomyces flora of Badia region of Jordan and its potential as a source of antibiotics active against antibioticresistant bacteria. J Arid Environ.; 53:365-371.

Saadoun, I., Al-Joubori, B. and Al-Khoury, R. (2015).Testing of production of inhibitory bioactive compounds by soil Streptomycetes as preliminary screening programs in UAE for anti-cancer and anti-bacterial drugs. Int. J. Curr. Microbiol. App. Sci. 4, 446-459.

Saadoun, I., L.Wahiby, Q. Ababneh, Z. Jaradat, M. Massadeh, and F. AlMomani.(2008). Recovery of soil Streptomycetesfrom arid habitats in Jordan and their potential to inhibit multi-drug resistant Pseudomonas aeruginosapathogens.World. J. Microb. Biot. 24:157-162.

Sambrook, J., Fritsch, E.F. and Maniatis, T. (1989) Molecular Cloning: A Laboratory Manual, 2nd Edition. Cold Spring Harbor: Cold Spring Harbor Laboratory.

Sherma, J. and Fried, B. (1996) Handbook of Thin Layer Chromatography. New York: Marcel Dekker.

Shiriling, E. M. and Gottlieb, D. (1966).Methods for characterization of Streptomyces species. Int. J. Syst. Bact. 16: 313-340.

Suthindhiran, K., M. A. Jayasri and K. Kannabiran. (2009). $\alpha$-glucosidase and $\alpha$ - 
amylase inhibitory activity of Micromonospora sp. VITSDK3 (EU551238). Int. J. Integr. Biol.6:115.

Takizawa, M., Colwell, R. and Hill R. T. (1993).Isolation and diversity of Actinomycetes in the Chesapeake Bay. Appl. Environ. Microbiol.59: 9971002.

Thornber K., Verner-Jeffreys D., Hinchliffe S., Meezanur Rahman M., Bass D., and Tyler C. R. (2020). Evaluating antimicrobial resistance in the global shrimp industry. Aquaculture.12, 966-986

Usha, R. Prabu E., Palaniswamy M., Venil C.K. and R. Rajendran (2010). Synthesis of Metal Oxide Nano Particles by Streptomyces $\mathrm{Sp}$ for Development of Antimicrobial Textiles.Global Journal of Biotechnology \& Biochemistry 5 (3): 153-160

Vela Gurovic M. S. and Olivera N. L. (2017). Antibacterial producing actinomycetes from Extra Andean Patagonia. J. Arid Environ. 144, 1-4. 10.1016/j.jaridenv.2017.04.015.

Williams ST, Goodfellow M, Alderson G, Wellington EM, Sneath PH, Sackin MJ.(1983). Numerical classification of Streptomyces and related genera. J Gen Microbiol129(6):1743-813.

Williams, S.T. and Cross, T. (1971). Actinomycetes. In: Methods in Microbiology. Pp. 29-65, (Booth, C. Ed.).Academic press, London.

Williams, S.T., Goodfellow, M. and Alderson, G. (1989). Genus Streptomyces.In Bergey's Manual of Systematic Bacteriology eds. Williams, S.T., Sharope, M.E. and Holt, J.M. pp. 2452-2492. Baltimore: Williams and Wilkins. 


\section{نهج جديد للتكوين الحيوي لعامل مضاد للميكروبات يتحكم في الكائنات الحية الدقيقة المقاومة لكلأدوية المتعددة}

$$
\begin{aligned}
& \text { 1أحمد سعدون ححم, 1أيمن فر اج احمد , *محمود محمد الأعصر , 1محم علي البدرى } \\
& \text { 1قنس النبات والميكروبيولوجي , كلية العلوم جامعة الاز هر } \\
& 2 \text { المركز الاقليمي للفطريات وتطبيقاتها بجامعة الاز هر }
\end{aligned}
$$

*mmelaaser@azhar.edu.eg: البريد الاكتروني للباحث الرئيسي

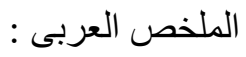

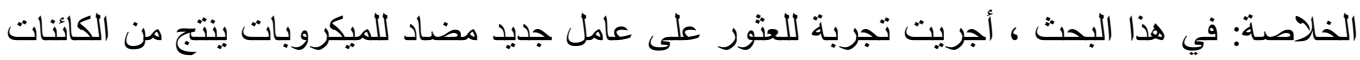

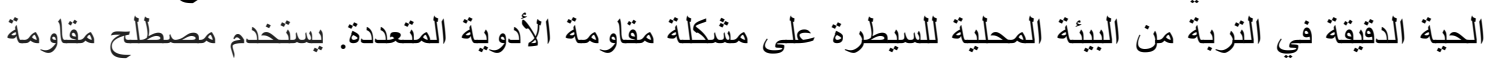

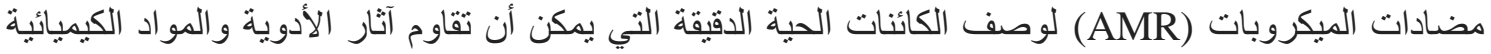

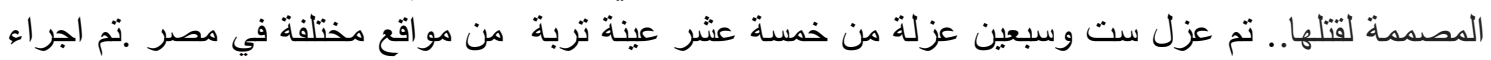

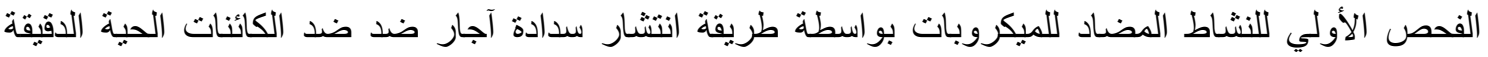

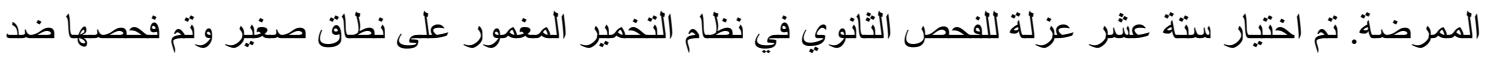

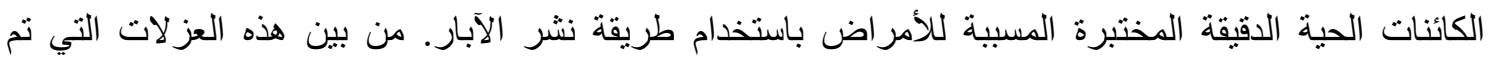

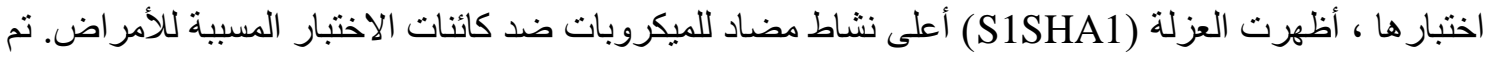

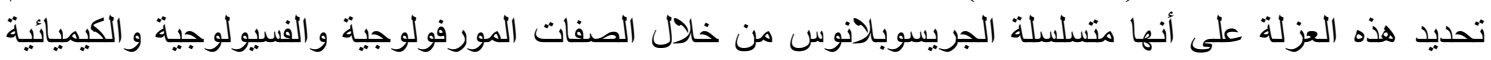

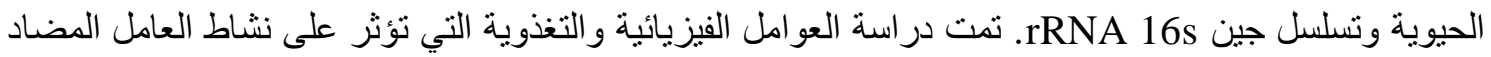

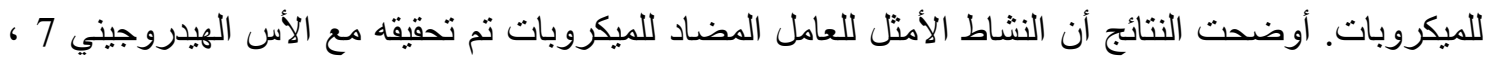

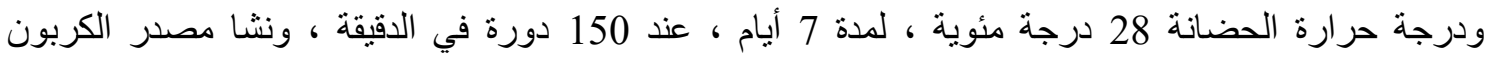

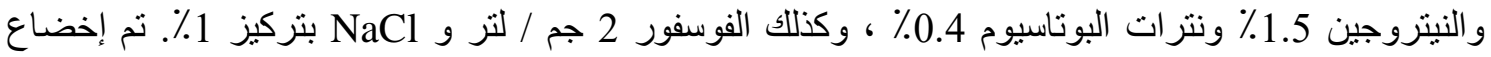

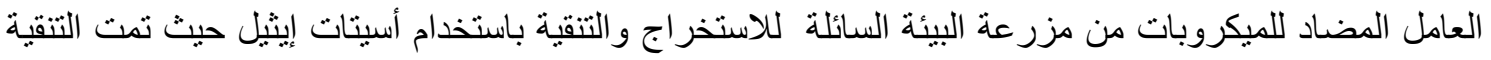

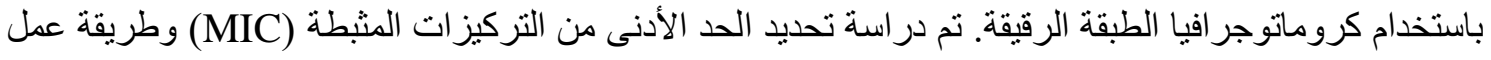

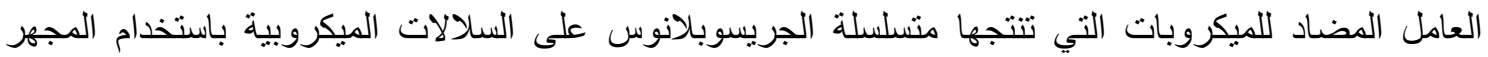

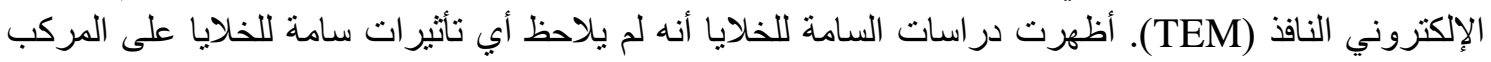
عند اختباره حنى بتركيزات عالية

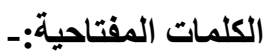

الكائنات الحية الدقيقة المسببة للأمر اض ،عامل مضاد للميكروبات ،المقاومة للأدوية المتعددة , سمية الخلايا. 